\title{
Paul's method of influence in 1 Thessalonians
}

Author:
M. Bruce Button ${ }^{1}$
Affiliation:
'Faculty of Theology,
North-West University,
Potchefstroom Campus,
South Africa
Corresponding author:
M. Bruce Button,
bruce@imago-web.co.za
Dates:
Received: 04 Mar. 2016
Accepted: 10 June 2016
Published: 19 Aug. 2016
code with your
How to cite this article:
Button, M.B., 2016, 'Paul's
method of influence in 1
Thessalonians', In die Skriflig
to read online.
50(2), a2113. http://dx.doi.
org/10.4102/ids.v50i2.2113
Copyright:
C 2016. The Authors.
Licensee: AOSIS. This work
is licensed under the
Creative Commons
Attribution License.

Although the field of leadership in the New Testament and in the Pauline Letters has received a great deal of attention, there are still many issues over which scholars disagree. It is proposed in this article that the ongoing use of insights from social-scientific models can help to clarify some of these issues. Those models should not be used in such a way as to impose themselves on the biblical text or the historical data, but to clarify concepts, create analytical categories and sensitise the New Testament scholar to new questions which can be asked of the text in its historical context. The article seeks insights from the power/interaction model of French and Raven, and analyses 1 Thessalonians in terms of some categories and concepts coming from the model. It is found that the primary way in which Paul sought to influence the Thessalonian community was by preaching the gospel and living a life that conformed to its values. The gospel as the good news of God's salvation in Christ is God's means of creating faith in and transforming the lives of those whom he calls.

\section{Introduction}

The subject of leadership in the New Testament, and particularly in the Pauline Letters, has received a great deal of attention, both from a scholarly and from an ecclesiastical perspective. ${ }^{1}$ One of the key issues in leadership is the question of power or influence. ${ }^{2}$ Although power is often viewed negatively as the imposition of one person's will upon another, it may also be understood more neutrally in the sense of influence. ${ }^{3}$ Understood in this way, power is of the essence of leadership, and the literature regarding leadership in Paul and in the New Testament has not ignored it. There are many studies which use various social theories to understand the functioning of social power in Paul. Some of these are highly critical of the apostle, accusing him of controlling and manipulating his converts (e.g. Castelli 1991; Shaw 1983), while others have a more positive assessment of his type of influence (Barentsen 2011; Ehrensperger 2007). Frequently the question of hierarchy becomes important, and the question is asked whether the Pauline churches were hierarchical in their structure and character (e.g. Clarke 2008:79-130; Tidball 2012). Other writers, from a wide variety of church traditions, seek to show that a biblical understanding of leadership emphasises God's power at work through the leader, rather than the leader's own authority, status, or ability to influence others (e.g. Kraybill 1999; Marshall 2004; Papademetriou 2003; Strawbridge 2009).

It is clear that the question of power and influence in church leadership is of both practical and theoretical importance, and the research referenced in the previous paragraph has generated a substantial body of knowledge on the subject. Nevertheless, there is a good deal of scholarly disagreement over many aspects of the topic. Scholars continue to give widely differing answers to such questions as whether the Pauline churches were hierarchical in structure and nature, whether the type of leadership exercised within them was authoritarian or more egalitarian, and whether Paul was manipulative and coercive towards his converts.

The answers that a particular scholar will give to these questions depend to some extent on his or her own ideological presuppositions, and especially the question of whether the New Testament documents' assumptions regarding the existence of God and his involvement in the world are to be taken seriously (Carson 2005:29-30). It is not only one's belief system, however, which determines the answers to these questions. Frequently a lack of clarity regarding definitions of key terms and the precise meaning of analytical categories like leadership and authority leads to

1.See Burtchaell (1992:1-179), Barentsen (2011:16-31) for useful surveys of the field. Recent monographs on the subject include those of Barentsen (2011), Burtchaell (1992), Campbell (1994), Castelli (1991), Clarke (1993; 2000; 2008), Ehrensperger (2007) and Polaski (1999).

2.Many leadership scholars include the concept of influence in their definition of leadership. See, for example, Bolden et al. (2011:39) Northouse (2013.5) and Yukl (2010:26). I have elsewhere discussed and proposed the following definition of leadership in the context of the Pauline churches: 'Leadership in the context of the early Pauline churches is a social process whereby a leader, empowered by the grace of God, influences members of the group to accomplish their common goals' (Button 2014:122-124).

3.See Button (2014:124-125) for further explanation and references. 
confusion in the discussion. For example, in Tidball's (2012) discussion of leadership versus servanthood, he seems to assume that leadership is somehow to be equated with authority and hierarchical power, but he does not define leadership or analyse these concepts in order to bring greater clarity to the discussion. Even Clarke's (2008) extensive monograph on the Pauline theology of leadership fails to define the central concept of leadership in any clear manner.

In this regard, Fika Van Rensburg (2000:570) has observed that New Testament scholars who work with social data, trying to do so without any kind of theory, do not actually do their work theory-free; rather, they work with naïve and intuitive theories which are undefined and untested. If this is true, research into leadership and influence in the Pauline churches and epistles will acquire greater clarity, and perhaps even some new answers, if light from some relevant social theories can be brought to bear.

I therefore propose in this article to analyse some of Paul's interactions with his converts using insights from the power/interaction model of interpersonal influence developed by social psychologists John French and Bertram Raven (French \& Raven 1959; Raven 1992; 1999; 2008). My method is not to use a 'pure' social-scientific approach ${ }^{4}$ (which would impose the model rigidly on the biblical and historical data), but to allow my own analysis to be informed and enriched 'by the questions social scientists ask and the models they employ' (Garrett 1992:90; Van Rensburg 2000:570). I will use the letter of 1 Thessalonians to supply a coherent body of data in which Paul's interactions with a group of his converts is documented.

\section{The French-Raven model of interpersonal influence Overview of the model}

The French-Raven model of interpersonal influence was first expounded by French and Raven (1959), and developed in subsequent papers by Raven $(1992 ; 1999 ; 2008)$. This model is based on the concept of social power, which may be understood as the potential (of an influencing agent) to effect a change in the beliefs, opinions, attitudes and behaviour of another person (the subject of influence) (French \& Raven 1959:150-151; Raven 2008:1). It is noteworthy that these types of change are precisely those which Paul desired to effect in his communities, and this observation creates an expectation that the French-Raven model may be helpful in analysing the Pauline process of influence. Within the French-Raven model, the influencing agent has a number of resources available by which such change may be effected in the subject of influence. Most often, these resources are considered to consist of six so-called bases of power (Raven 2008:1). To better understand how they work, these six bases of power can be grouped into three categories as follows:

\footnotetext{
4.By "'pure" social-scientific approach' I mean an approach which takes social theories as they stand and attempts to apply them to the biblical and historical data Fika Van as they stand and Rensburg (2000:570) notes that the problem with such an approach is that focuses one-sidedly on social theories and models which have been developed on the basis of modern phenomena; the biblical data are treated as secondary.
}

1. Power that leads to change which is socially dependent, with surveillance necessary: reward power, and coercive power.

2. Power that leads to change which is socially dependent, with surveillance unnecessary: legitimate power, referent power, and expert power.

3. Power that leads to change which is socially independent: informational power (Raven 2008:2-3).

These six bases of power are now defined.

\section{Reward and coercive power}

Reward power is power which an agent has over a subject by virtue of the agent's ability to reward changes in the subject. Such reward may involve the provision of positive consequences or the removal of negative ones. The strength of an agent's reward power depends on the magnitude of the reward offered, and on the probability (as perceived by the subject) that the agent will actually administer the reward. Thus, a piece-work rate for factory workers is often effective because they can easily see that there is a high probability (almost a certainty) that an increased rate of work will be rewarded. This form of power leads to change which is socially dependent: the change persists only as long as the subject believes that the agent will provide the reward. Furthermore, the change requires surveillance because the influencing agent can provide the reward only as long as he or she is aware that the change has in fact occurred in the subject (French \& Raven 1959:156-157; Raven 2008:2).

Coercive power is the negative correlate of reward power. It is derived from the power an agent has to punish a subject by providing negative consequences or removing positive ones. As in the case of reward power, the strength of coercive power depends on the perceived probability of punishment and the magnitude of the punishment. Coercive power, like reward power, is socially dependent and requires surveillance (French \& Raven 1959:157; Raven 2008:2).

\section{Legitimate power}

Legitimate power is the most complex of the six bases of power. It derives its force from a societal norm or value on the basis of which someone has an obligation. On the basis of such a norm or value, a particular type of behaviour or belief has an 'oughtness' about it (French \& Raven 1959:158-160; Raven 2008:3). One of the most common types of legitimate power is what may be called legitimate position power. This form of power is based on the norm (present in most societies) that a person in a position of authority should be obeyed (French \& Raven 1959:159; Raven 1992:220). Raven also notes that legitimate power may take other forms, for example:

- Legitimate power of reciprocity whereby a person has a perceived obligation to help someone who has helped him or her.

- Legitimate power of equity whereby one who has suffered has the perceived right to ask a more fortunate person to help him in his need (p. 220). 
Legitimate power is socially dependent because in this form of power the subject makes changes in his or her beliefs and behaviour in response to indications (direct or indirect) of what the influencing agent requires. When there is no perception that the influencing agent requires anything, there is no exercise of legitimate power. This form of power, however, does not require surveillance because the force of the influence does not come from any action on the part of the agent, but from a norm or value that has been internalised in the subject (French \& Raven 1959:161).

An understanding of legitimate power has the potential to contribute significantly to our understanding of leadership in the Pauline churches, particularly the question of whether leadership was hierarchical. In addition to trying to discern the presence or absence of a hierarchical structure, as is often done, ${ }^{5}$ this model enables one to examine the interactions (or influence attempts) between leaders and followers, and to ask whether these interactions evidence an attempt to influence people by appealing to one's position (i.e. by exercising legitimate position power). In this way one can assess the historical situation on the basis of more direct data, rather than relying only on less direct historical reconstructions.

\section{Referent power}

Referent power is derived from the subject's identification with the agent. A subject who desires to be like the influencing agent may modify his or her beliefs and behaviour to conform to those of the subject (French \& Raven 1959:161-162). This kind of change usually takes place without the agent even knowing what the subject is thinking. Surveillance is therefore unnecessary in the exercise of referent power, and the change is socially dependent because the subject makes the change on the basis of the influencing agent's beliefs and behaviour. French and Raven (1959:163) do note, however, that 'there is probably a tendency for some of these dependent changes to become independent of [the agent] quite rapidly.'

\section{Expert power}

Expert power is an ability to influence derived from the subject's confidence that the influencing agent has knowledge which he or she does not have. The subject will follow the agent's instructions because the agent is perceived to be an expert, that is to know better. The exercise of this type of power is common in society, being found, for example, in lawyer-client or doctor-patient interactions (French \& Raven 1959:163; Raven 2008:3). Expert power is socially dependent, as it can only function when the subject perceives that an influencing agent knows better, and that the agent has given some sort of advice or instruction. Expert power does not require surveillance because it does not depend on the agent knowing how the subject responds to the influence attempt; the subject responds on the basis of his or her own perception of the agent, irrespective of how the agent responds.

5.See, for example, the discussion of Tidball (2012:42-43), who argues that the family structure of Christian communities gave them a hierarchical character.

\section{Informational power}

Informational power is the last of the generally recognised bases of power. It differs significantly from the others in that it is both socially independent and does not require surveillance. ' $[I t]$ is based on the information, or logical argument, that the influencing agent can present to the [subject] in order to implement change' (Raven 1992:221). Informational power is sometimes confused with expert power, but differs from the latter in that the subject is led to understand the reason for the change desired by the influencing agent (Raven 2008:3). This is why it is socially independent: once the subject understands the reason, he or she no longer needs an agent to exert influence in order to maintain the change.

\section{General comments on the model}

It is important to note that in most cases an influence attempt will be successful only if certain preconditions are in place. For example, reward or coercive power will be effective only if the subject is convinced that the influencing agent is indeed able to administer the applicable rewards or punishments; expert power will only be effective if the subject has confidence in the agent's knowledge and expertise; legitimate power will only be effective if the subject has internalised the relevant societal norms and values; referent power depends on a certain relationship between agent and subject. Depending on the situation, these preconditions may already be in place; however, if they are not, an agent will need to do some 'stage-setting' before he or she is able to make effective use of the bases of power. One who desires to use expert power may display his degrees and certificates in a prominent place; one who wishes to use coercion may make a display of her power by intimidating those she seeks to influence (Raven 1992:223-225). Raven (226-227) notes that it is important to distinguish between an actual exercise of power and a preparatory device.

It is important to observe that all six of these bases of power depend for their effectiveness on the cognition, emotions and psychological state of the subject, and on the way in which the influencing agent appeals to the subject's cognition, emotions and psychological state. Raven (1992:222) points out that there are other forms of power that are not so dependent. One that he mentions is environmental or ecological manipulation, in which the agent modifies the subject's environment in such a way as to bring about certain behaviour; an example would be erecting a fence to prevent trespassers from entering a property. In this case a 'power' or 'force' external to the subject effects a change in the subject. Another form of manipulation is exemplified by a psychiatric nurse keeping unruly patients busy during the day so that they are unable to disrupt the ward at night (Raven 1992:222). This observation will prove important when considering how Paul sought to influence his communities.

Two final comments are necessary. Firstly, it must be noted that any of these bases of power can be used by one person on behalf of or in the name of a third party. The third party so invoked may possess any of the six bases of power, and any 
of these may be appealed to (Raven 1992:222-223;2008:15-16). Raven (1999) draws heavily on this idea in his analysis of religion, notably Judaism and Christianity, which are based on the Bible. In his analysis much religious discourse about God is understood as an appeal to an invented superior being; this being is appealed to as a third party with much greater reward, coercive and legitimate power than the religious and other leaders who invoke his power. Secondly, in any given practical situation there is usually more than one of the six bases of power at work (Raven 2008:14). This does complicate the analysis, but if the point is not borne in mind the analysis may easily become confused.

\section{Analysis of Paul's influence in 1 Thessalonians \\ Change in the Thessalonian believers' lives}

Although it may be tempting at this point to analyse 1 Thessalonians in terms of the six bases of power explained above, it is important to begin with a more conceptual approach, in line with the methodology proposed in the Introduction. It was noted there that I would allow my own analysis to be informed and enriched by the questions social scientists ask and the models they employ, rather than simply attempting to apply a model as it stands. While the FrenchRaven model is best known for its six bases of power, its usefulness for understanding the phenomena of the New Testament extends far beyond that schema. As becomes clear from the description in the previous section, the French-Raven model provides analytical categories which give insight into many aspects of interpersonal interaction and influence. Such categories include the idea of change, the question of social dependency, the belief systems and thought processes which allow certain types of influence attempt to be effective. An understanding of these analytical categories also sensitises the interpreter to the limits of the six-fold schema and to the possible need for additional bases of power that will properly explain the data in question. In view of this conceptual wealth, the model will best serve an understanding of Paul's influence in 1 Thessalonians if the analysis is begun using categories that are more fundamental than the six bases of power.

As a starting point it is helpful to note that the purpose of power and influence is to bring about certain changes in the person influenced. I therefore begin by listing some key passages in 1 Thessalonians which delineate change which had been brought about through Paul's ministry, and changes which he still sought to bring about. ${ }^{6}$ (The type of change involved is noted in square brackets after each passage.):

For we know, brothers loved by God, that he has chosen you, because our gospel came to you not only in word, but also in power and in the Holy Spirit and with full conviction [change of belief and religious loyalty, conversion]. (1 Th 1:4-5) ${ }^{7}$

6.The authors of 1 Thessalonians are said to be Paul, Silvanus and Timothy (1 Th $1: 1$ ), and the letter is written in the first person plural. There has been much debate as to whether the letter was actually written by all three of the persons mentioned in v1, or whether the letter was actually written by all three of the persons mentioned in v.1, or whethe the plural had another function and the letter was written by Paul alone (see Malherbe 2008:86-89 for discussion). Without making any assertions regarding the answer to this question, I accept in the following discussion that the letter expresses the
thinking of Paul. Accordingly, I will generally refer only to Paul as the author.

7.Unless otherwise indicated, all scripture quotations are from the English Standard Version (ESV).
... you turned to God from idols to serve the living and true God, and to wait for his Son from heaven [change of belief and religious loyalty, conversion]. (1 Th 1:9-10)

... we exhorted each one of you and encouraged you and charged you to walk in a manner worthy of God, who calls you into his own kingdom and glory [ethical obedience]. (1 Th 2:12)

And we also thank God constantly for this, that when you received the word of God, which you heard from us, you accepted it not as the word of men but as what it really is, the word of God, which is at work in you believers [change of beliefs, ethical transformation]. (1 Th 2:13)

But now that Timothy has come to us from you, and has brought us the good news of your faith and love and reported that you always remember us kindly and long to see us, as we long to see you - for this reason, brothers, in all our distress and affliction we have been comforted about you through your faith. For now we live, if you are standing fast in the Lord [ongoing faith and perseverance]. (1 Th 3:6-8)

... may the Lord make you increase and abound in love for one another and for all, as we do for you, so that he may establish your hearts blameless in holiness before our God and Father, at the coming of our Lord Jesus with all his saints [ethical obedience]. (1 Th 3:12-13)

Finally, then, brothers, we ask and urge you in the Lord Jesus, that as you received from us how you ought to walk and to please God, just as you are doing, that you do so more and more. For you know what instructions we gave you through the Lord Jesus. For this is the will of God, your sanctification: that you abstain from sexual immorality [ethical obedience]. (1 Th 4:1-3)

Now concerning brotherly love you have no need for anyone to write to you, for you yourselves have been taught by God to love one another, for that indeed is what you are doing to all the brothers throughout Macedonia. But we urge you, brothers, to do this more and more [ethical obedience]. (1 Th 4:9-10)

We ask you, brothers, to respect those who labor among you and are over you in the Lord and admonish you, and to esteem them very highly in love because of their work [interpersonal behaviour]. (1 Th 5:12-13)

Now may the God of peace himself sanctify you completely, and may your whole spirit and soul and body be kept blameless at the coming of our Lord Jesus Christ [thoroughgoing transformation of the whole person]. (1 Th 5:23)

These passages show that the type of change which Paul sought in the Thessalonians began with a profound change of belief and religious loyalty (i.e. conversion), embraced ongoing faith and perseverance, entailed ethical obedience, and culminated in thoroughgoing transformation of the whole person. Influencing people in such a way as to bring about this kind of change is the goal of leadership in Paul's thinking, and any discussion of leadership in Paul must not ignore this perspective. The kind of influence, or power, required to effect this change must be truly remarkable.

\section{The keys to power: Gospel and faith}

Very early in 1 Thessalonians there is an indication of the power which produced the initial change (conversion) in the Thessalonians. As part of his opening thanksgiving, Paul thanks God because he knows that God has chosen them (1 Th 1:4-5). The Greek text reads: 


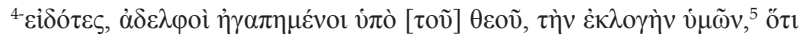

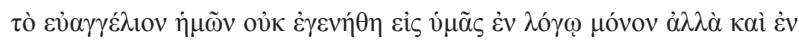

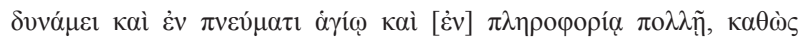

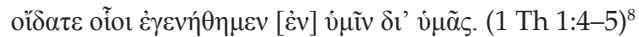

In this passage Paul states that he knows the Thessalonians'

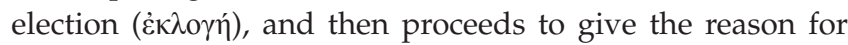
this assurance (ö $\tau 1 \kappa \tau \lambda$, with ö $\tau$ understood in a causal sense). ${ }^{9}$ Three reasons are given, all relating to the way Paul's gospel came to the Thessalonians:

1. Our gospel came not only in word but also in power: Paul does not deny the use of words (and, no doubt, reason), but he claims that there was a power which accompanied those words (Wanamaker 1990:79).

2. ... in the Holy Spirit: The source of the power that was present in Paul's preaching was the Holy Spirit (Fee 2011:44-45).

3. ... with much conviction: Although some commentators (e.g. Wanamaker 1990:79) take this to refer to the conviction with which Paul preached the gospel, it is far more natural to understand it as a reference to the Thessalonians' response to the gospel. The purpose of the ö $\tau$ clause is to provide evidence for the Thessalonians' election, but it is only this final phrase which describes a visible result that can provide evidence of election; even the power and the presence of the Holy Spirit in Paul's preaching - at least as far as they relate to conversion had to be inferred from the visible change in the Thessalonians' belief system. The logic is: the Thessalonians' conviction regarding the gospel could only have come about through the power of the Spirit working in them (i.e. calling them); this is evidence that God has chosen them because 'those whom [God] foreknew [i.e. elected] ... he also called' (Ro 8:29-30). What is described here as conviction is closely associated with faith, because the essence of the Thessalonians' response to the gospel is elsewhere referred to as faith, or (in verbal form) believing (1 Th 1:8; 2:10, 13).

This passage shows that the fundamental cause of the change which occurred in the Thessalonian believers at their conversion was the power of God working through the gospel by the Spirit. The essence of the conversion itself was that these Thessalonians became believers, people whose faith in God was reported all over Macedonia and Achaia (1 Th 1:8).

Further examination of 1 Thessalonians shows the foundational role of the gospel and of faith. Not only in 1:4-5, but also in 2:1-13, where Paul's initial ministry to the

8.Ail quotations from the Greek text of the New Testament are taken from the 28 th revised edition of the Nestle-Aland Novum Testamentum Graece.

9.Some commentators interpret the ö $\tau$ clause epexegetically, so that it provides an elaboration on Paul's statement that he knows [the Thessalonians'] election: 'We know ... God's choosing of you in that our gospel came to you ...' (e.g. Best 1979:73; Malherbe 2008:110). Although the grammatical form of the sentence

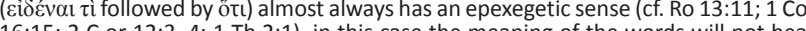
$16: 15 ; 2$ or $12: 3-4 ; 1$ Th 2:1), in this case the meaning of the words will not bea an epexegetic interpretation. In Paul's thought election precedes God's act of calling election takes place in God's eternal counsel, whereas calling takes place concretely in history (cf. Ro 8:28-30; 9:11; 11:5,28; Eph 1:4). Thus v. 5, which deals with the actual divine call, cannot be a description of the Thessalonians' election; it must supply the reason why Paul knows that the Thessalonians were chosen by God.
Thessalonians is described in some detail, the preaching of the gospel - three times designated as the 'gospel of God' - is central $(2: 2,4,8,9)$. When Paul describes his sending of Timothy to encourage the persecuted believers, he calls Timothy 'God's co-worker in the gospel' (3:2). 'Faith' in either

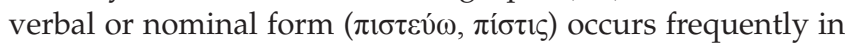
the early part of the letter: in 1:3 the Thessalonians' work is said to come from faith; in 1:8 their faith is reported; in 2:10,13 they are described as 'those who believe'; most importantly, in chapter 3 Timothy is sent to encourage their faith (3:2), to find out about their faith (3:5), and to bring Paul good news about their faith (3:6-7); in 3:10 Paul desires to see them in order to supply what is lacking in their faith. Malherbe (2008:85) sums up Paul's approach as follows: 'Although he uses the conventions of the moral philosophers, he is no philosopher but a preacher of the gospel. And the content of the message he had preached was not moral teaching aimed at personal betterment, but the word of God that aimed at generating faith' (emphasis added). ${ }^{10}$

It becomes evident, therefore, that in Paul's mind the gospel and faith were central to the power which was at work in the Thessalonian believers. A wider consideration of these concepts in Paul's thinking will bear this out and clarify the relationship between them.

There is no doubt that the gospel was central in Paul's thinking. In Romans 1:1 Paul states that he is set apart for the gospel; in 1 Corinthians 15:1-3 that he delivered the gospel 'as of first importance', that believers stand in it and are saved through it. Dunn (1998:165) notes that Paul's concern for the gospel: ' $[m]$ ore than any other of [his] key themes ... remains constant throughout [his] written ministry.' Key aspects of Paul's understanding of the gospel include:

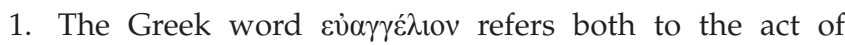
proclamation and to the content of that proclamation; these two are closely related (Lohse 1995:130; Wanamaker 1990:78).

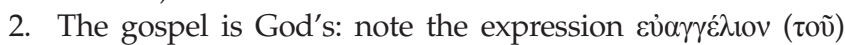
$\theta \varepsilon$ ov in Romans 1:1; 1 Thessalonians 2:2, 8, 9. This means that God is the 'source and authority of the message ... [h]e is the one who has acted to bring salvation' (O'Brien 1995:67).

3. Above all, the gospel concerns Jesus Christ. It includes the message of his life, death, resurrection, ascension, and his powerful kingly reign (Ro 1:1-4; 1 Cor 15:3-8; Dunn 1998:181; Lohse 1995:130).

4. The gospel is rooted in salvation history and proclaims Christ as the fulfilment of the Old Testament, the one who brings God's eschatological salvation to mankind (Ro 1:2-3; O'Brien 1995:67).

5. The gospel 'mediates the almighty power of God that leads to salvation. It is not that the gospel simply speaks about divine power; it is God's power leading to deliverance on the last day' (O'Brien 1995:71, original emphasis; Ro 1:16; 1 Th 1:10). Thus the preaching of the gospel is the means by which God makes the reign of Christ a reality: 'it is through Paul's preaching that Jesus, the king of Israel, takes the nations in captive obedience to himself

10.cf. Malherbe (1983:249): "Paul regards his entire ministry, as to its origin motivation, content and method, as being directed by God. God grants him the boldness to speak, and what he says is not philosophical or rational analysis of the human condition, but the gospel of God.' 
(cf. Gen 49:10; Ps 2:8f.). Paul therefore portrays his mission as the instrumentality by which the risen Christ in the fullness of time asserts his rule over the new people of God' (Garlington 1990:203).

6. Paul's theology, including his theology of the gospel, arose out of his own experience of divine grace. For him, conversion was a 'transition to a different plane'. The 'sense of eschatological newness which transformed and continued to sustain Paul's theology ... gave his theology its cutting edge' (Dunn 1998:179-180).

This brief survey shows that, in Paul's mind, the changes which he desired to see in those to whom he ministered were brought about by the power of God, working through the gospel. However, to understand the power of the gospel properly, it must be understood in relation to faith.

The power of God working through the gospel bears a twofold relationship to faith. In the first place, it is the power of the gospel which begets faith in those hearers whom God calls to himself. This is the working of the gospel which is described in 1 Thessalonians 1:4-5 (see above). It is also clearly stated in Romans 10:17: 'So faith comes from hearing, and hearing through the word of Christ.' (In the context, the word of Christ is the preaching of the gospel - Ro 10:15). ${ }^{11}$ The gospel is the power of God inasmuch as through it, 'the heart is moved to ... faith by the same creative word of God as that by which he caused the light to shine on the darkness of the primeval time' (Ridderbos 1975:235).

The second way in which the power of the gospel is related to faith has to do with the ongoing experience of the Christian life. For one who has already experienced the faith-creating power of the gospel, faith becomes the means by which the reign of grace is experienced in its power to transform the believer into conformity with the image of Christ (Ro 1:17 with Ro 5:21). 'To live by faith in the Son of God means to live out of the resources given by the Son of God and out of the motivation inspired by the Son of God's self-giving' (Dunn 1998:637).

\section{Forms of influence in 1 Thessalonians}

\section{An extension of the French-Raven model}

Having noticed the type of change desired by the apostle Paul, and observed the central place of faith and the gospel in Paul's relationships with the Thessalonian believers, I now proceed to an analysis of Paul's influence on the Thessalonian believers in terms of French and Raven's bases of power. Before applying the model it is important to note, on the basis of the foregoing discussion regarding the gospel and faith, that the six common bases of power are inadequate to explain the type of influence which is observed in 1 Thessalonians. As pointed out on page 3 above ('General comments on the model'), the six common bases of power depend for their effectiveness on the cognition, emotions and psychological state of the subject, and on the way in which the influencing agent appeals to the subject's cognition, emotions and psychological state. There are other forms of power like environmental manipulation which affect the subject's behaviour beyond his or her own power to think, feel and decide. In the case of the Thessalonians' conversion and perseverance in the faith, there were powers at work in them beyond their own cognitive and psychological response to Paul's influence attempts, which came in the form of gospel preaching and other types of interaction. Paul states explicitly in the letter that God's power was at work in them by his Spirit through the gospel, and that the power for change came ultimately from God (1 Th 1:5; 2:13; 3:12-13; 4:9; 5:23). A more comprehensive view of Paul's thinking regarding the gospel and faith (pages 4 to 6) confirms and deepens this understanding of how change was effected in the Thessalonians' lives.

It therefore becomes necessary to extend the French-Raven model by defining another form of power, which I have termed spiritual power, to reflect adequately the dynamics at work in the interface between Paul and the Thessalonians. Spiritual power is defined as follows: ${ }^{12}$

Spiritual power is found where God graciously equips a person to minister the gospel effectively so that the recipients of the ministry put their faith and trust in God through Christ as he is revealed in the gospel. Both the ministry and the response are the effects of God's gracious working.

I now analyse some key passages in 1 Thessalonians using this extended model of power/interaction.

\section{Thessalonians 1:2-10}

In this opening chapter of the letter spiritual power is prominent. Paul states in verses 5-6 that the gospel was preached in Thessalonica, and verses 9-10 indicate something of the content of the gospel as it concerns God's eschatological work of salvation through Jesus Christ. ${ }^{13}$ However, the way Paul expresses himself in this passage draws attention to the power and effect of the gospel rather than its content (Malherbe 2008:125). As discussed on pages 4-5 ('The keys to power: gospel and faith'), the Thessalonians' response (conversion) was brought about by the power of the Holy Spirit through the gospel, not simply by human persuasion.

There are indications of other bases of power at work as well. The fact that certain content regarding the gospel was communicated and understood indicates the operation of informational power (vv. 5, 6, 9-10). The reference to the Thessalonians following Paul's example (v. 6) may seem to be an indication of referent power. However, their imitation may not have been a 'conscious commitment to imitate Paul'; rather, it was acceptance of the gospel which 'had the effect of making the converts imitators of Paul and the Lord' (Malherbe 2008:127). There is an indication of reward power at work in verse 3 ('steadfastness of hope') ${ }^{14}$ and verse 10 ('Jesus who delivers us from the coming wrath'). In this case

12.See Button (2014:129-132) for further discussion and explanation of spiritual power.

13. Malherbe (1987:30) notes that 1 Th 1:9-10 is widely thought to preserve the outline of a typical Pauline sermon.

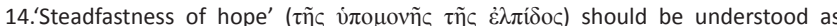
'steadfastness arising from hope' ( $\dot{\delta} \lambda \pi i \delta$ ó $c$ is interpreted as a subjective genitive indicating source or origin), the thought being that the hope of eternal salvation indicating source or origin), the thought being that the hope of eternal salvation
motivates believers to endure hardship and loss in the present world, knowing that motivates believers to endure hardship and loss in the prese 
it would be the reward which God offers, so the use of these ideas by a preacher such as Paul would represent the invocation of a third party. However, it would be a misunderstanding of this passage to think of the reward of deliverance as a decisive motivation by itself. It was an essential part of the gospel to offer deliverance at the final judgement - and at the human level this would have been a motivating factor once the gospel's world view had been accepted - but conversion resulted from the work of the Spirit enabling believers to commit their lives to Jesus as the Son of God invested with power to bring God's eschatological salvation to mankind. In both verse 3 and verse 10 attention is drawn to Jesus Christ.

\section{Thessalonians 2:1-13}

First Thessalonians 2:1-13 is particularly important when seeking to understand the way in which Paul sought to influence people. These verses describe in some detail his (and his fellow missionaries') manner of life and ministry among the Thessalonians on their founding visit. There is much disagreement among scholars as to the purpose of this passage, especially over the question of whether Paul was defending himself against attacks on his integrity. ${ }^{15}$ For the present purpose it is enough to recognise that the passage

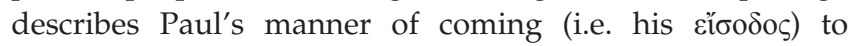
Thessalonica and that he sought to distinguish himself from the popular philosophers of the day - on this point there is general agreement. ${ }^{16}$

In this passage the essential characteristic of Paul's ministry among the Thessalonians is described three times as a proclamation of the gospel (vv. 2,8,9); in all three instances the gospel is called the gospel of God, and this explains the statement in verse 4 that he has 'been approved to be entrusted with the gospel'. All of this implies that Paul was aware of dealing with something which did not belong to him, and that it needed to be respected as something given in trust. The gospel had its own power (v. 13), and it had to be handled in such a way as not to interfere with that power by combining its ministry with self-centred motives or deceptive methods (vv. 3-5). This emphasises spiritual power as the primary basis of power at work in Paul's 'coming' to Thessalonica. The denial of deceptiveness, error, impurity and greedy motives (vv. 3-5), combined with a reminder of Paul's self-denying love and concern (vv. 7-9), and of his righteous conduct (v. 10), show that for spiritual power to be effective the life of the messenger must embody the values of the gospel itself - the gospel which announces God's own love embodied in the selfless love of Christ (cf. 2 Tm 2:21). ${ }^{17}$ This close relationship between the messenger and the message is reflected also in 2 Corinthians 5:11-21.

15.For a survey of the debate and a defence of the apologetic interpretation see (Weima 1997); Malherbe (2008:153-154) and Wanamaker (1990:90-91) both reject this interpretation, understanding the passage rather as a form of paraenesis.

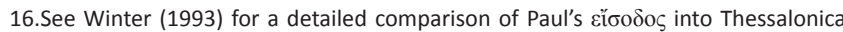
with that of the philosophers.

17.Cf. Malherbe (2008:113): 'The personal relationship between Paul and his readers was formed when he conducted himself in a manner ... that could not be separated from the manner in which he preached.'
It is significant to note what is denied in verses 6-7. The first part is clear ('Nor did we seek glory [i.e. honour] from people'), but the second part (translated as 'though we could have made demands as apostles of Christ' ${ }^{18}$ is interpreted in many different ways. Bruce (1982:30-31) understands غ̇v $\beta \alpha ́ p \varepsilon 1$ as a reference to financial support - tempting in light of verses 8-9, but it is not clear that requiring financial support would be a means of seeking honour; Malherbe (2008:144) relates it to harshness and scolding, which seems a bit contrived in the context. The most natural understanding is

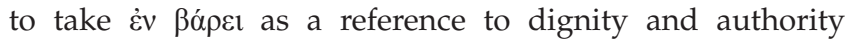
(Wanamaker 1990:99), so that the clause could be translated: 'though as Christ's apostles we could have come to you as heavyweights'. The contrasting positive assertion - $\dot{\alpha} \lambda \lambda \dot{\alpha}$

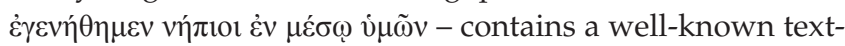

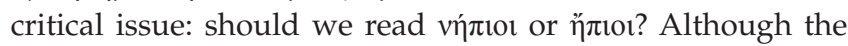
former is better attested, it has seemed harsh to many commentators, ${ }^{19}$ hence the translation ' $g e n t l e$ ' in the ESV and most other English translations. However, Fika Van Rensburg (1986) wrote an important article on this question in which he argues for the more difficult reading, ví $\pi$ iot. Others have agreed (Weima 1997:96, n.64; 2002:214-215), and there is indeed good reason for accepting this reading: rather than coming to the Thessalonians with a demand for status and authority, Paul came as an infant, one who had no power or status (cf. Mt 18:1-4; Lk 9:46-48). ${ }^{20}$ The implications of these statements for the use of power are significant. Status, dignity and authority would be associated with legitimate power. Yet Paul deliberately shunned this approach, choosing instead to become powerless so that the power of the gospel would be emphasised (cf. 1 Cor 2:3-5) - a confirmation that spiritual power was uppermost for the apostle.

Paul's gentleness and consideration in working so as to avoid placing a financial burden on the Thessalonians (vv. 7-9) is best understood as belonging to the 'stage-setting' phase of influence, ${ }^{21}$ rather than being an influence attempt in and of itself. Of the six common bases of power, this kind of stage setting might most easily be associated with referent power (in that it builds a positive relationship between Paul and his community). However, it fits very well with spiritual power in that it demonstrates the messenger's integrity and the congruence of his life with the message preached.

Finally, it is important to consider Paul's reference to his exhortation in verses 10-12. There is a clear indication of referent power at work here, in that Paul's life provided an example for the Thessalonians. Some scholars would take Paul's reference to himself as a father as an appeal to his authority (legitimate power), especially if the idea of the paterfamilias is understood to be behind this reference (see Tidball 2012:42-43). This may be part of the dynamic, but it should be noticed that the reference to fatherhood is framed

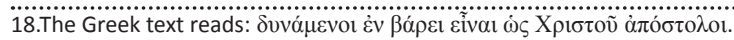

19.Bruce (1982:31); Malherbe (2008:145-146); Wanamaker (1990:100).

20.Note the re-punctuation required for acceptance of this reading (Van Rensburg 1986:255; Weima 1997:96, n.64).

21.See pages 3-4 above ('General comments on the model'). 
by 'how holy and righteous and blameless was our conduct ...' at the beginning and 'God who calls you ...' at the end. The first points in the direction of referent power, and the second draws attention to God's calling. The appeal to 'walk in a manner worthy of God' is certainly an instance of (third party) legitimate power, but it should be observed that this is closely associated with a reminder of the basic truths of the gospel ('who calls you into his kingdom and glory'), another reminder of the centrality of spiritual power.

\section{Thessalonians 4:1-12}

Scholars agree that this passage constitutes explicit paraenesis, with an emphasis on specific instructions and motivations for obeying those instructions. As such, a wider range of power bases is in evidence than in the descriptions of Paul's initial ministry, especially insofar as that ministry is associated with the Thessalonians' conversion. Firstly, it may be noticed that there is something of an appeal to expert power in the statements 'you received $(\pi \alpha \rho \varepsilon \lambda \alpha \dot{\beta} \varepsilon \tau \varepsilon)$ from us ... instructions we gave you through the Lord Jesus' (vv.1-2). The verb $\pi \alpha \rho \alpha \lambda \alpha \mu \beta \alpha ́ v \omega$ points to the reception of oral tradition (of which Paul was claiming to be an authorised custodian), and the statement 'through the Lord Jesus' probably points to Paul's apostolic authority (Wanamaker 1990:148-149). Paul is at this point aiming to convince the Thessalonians regarding the will of God (v. 3), and his reference to tradition and apostolic authorisation give reasons why they should accept his word as correct (expert power). The appeal to tradition would also have elements of informational power insofar as this tradition could be checked independently of Paul.

Throughout this passage there is an emphasis on power exercised on behalf of a third party in that the appeals cause the Thessalonians to stand before the face of God; hence verse 8: "Therefore whoever disregards this, disregards not man but God'. God's legitimate power is expressed in the phrases 'you ought to walk to please God' (v. 1), and 'this is the will of God' (v.3). Coercive power may be recognised in the strong adjuration, 'because the Lord is an avenger in all these things, as we told you beforehand and solemnly warned you.'

Yet, for all these sometimes frightening assertions, the reality of the gospel is woven throughout the paraenesis. The Thessalonian believers must abstain from sexual immorality because, unlike the Gentiles, they know God (v. 5). They are motivated to holiness rather than impurity because of God's calling (v. 7). God's instructions must not be disregarded because he gives his Holy Spirit (v. 8). They are able to love one another because they have been taught by God to do so (v. 9). Thus, spiritual power is again prominent, and this explains Paul's concern for the Thessalonians' faith, as expressed repeatedly in chapter 3 . Although there is not space to consider in detail the rest of the paraenesis in chapters $4-5$, a careful reading will show that spiritual power is prominent there too.

\section{Summary and conclusion}

The aim of this article is to bring some clarity to the question of how Paul thought about the question of influence, and how he sought in practice to influence his communities. In order to do so, I have made use of the French-Raven model of power/interaction, not as a model to be imposed on the historical data or the biblical text, but as an aid to thinking more clearly about the social and spiritual dynamics of a Pauline community, especially as they relate to the question of leadership. The model has helped to identify some important analytical categories which give greater insight into the phenomenon of interpersonal influence in a Christian community. These categories include the idea of change produced in the subject of influence, and the dynamics by which an influencing agent can bring about change. An analysis of Paul's first letter to the Thessalonians has shown that, in the case of Paul and the Thessalonian community, the change (conversion and sanctification) was not effected simply by acting on people's thinking and emotions; rather, it was effected by the power of God acting by his Spirit through the gospel - the announcement of the good news that God has acted in Christ to inaugurate the long-awaited age of salvation. This leads to an extension of the French-Raven model to include another basis, spiritual power. More detailed analysis of 1 Thessalonians in terms of this extended model shows that spiritual power is indeed at the heart of Paul's influence.

The article highlights the importance of using social-scientific models in a flexible way. A rigid application of the FrenchRaven model only in terms of its six bases of power would have identified correctly some of the social interactions represented in 1 Thessalonians, but would have missed the central dynamic of spiritual power. Allowing the model to inform and enrich the analysis in a more flexible way makes it a powerful tool for understanding the data of the New Testament.

\section{Acknowledgements Competing interests}

The author declares that he has no financial or personal relationships which may have inappropriately influenced him in writing this article.

\section{References}

Barentsen, J., 2011, Emerging leadership in the Pauline mission: A social identity perspective on local leadership development in Corinth and Ephesus, Pickwick Publications, Eugene, OR.

Best, E., 1979, A commentary on the First and Second Epistles to the Thessalonians, Adam \& Charles Black, London.

Bolden, R., Hawkins, B., Gosling, J. \& Taylor, S., 2011, Exploring leadership: Individual, organizational \& societal perspectives, Oxford University Press, Oxford.

Bruce, F.F., 1982, 1 \& 2 Thessalonians, Word Books, Waco, TX.

Burtchaell, J.T., 1992, From synagogue to church: Public services and offices in the earliest Christian communities, Cambridge University Press, Cambridge.

Button, M.B., 2014, 'Leadership and the gospel in the early Pauline churches', PhD thesis, Department of New Testament, North-West University, Potchefstroom Campus.

Campbell, R.A., 1994, The elders: Seniority within earliest Christianity, T\&T Clark, London.

Carson, M.L.S., 2005, 'For now we live: A study of Paul's pastoral leadership in 1 Thessalonians', Themelios 30(3), 23-41.

Castelli, E.A., 1991, Imitating Paul: A discourse of power, Westminster John Knox Louisville, KY.

Clarke, A.D., 1993, Secular and Christian leadership in Corinth: A socio-historical and exegetical study of 1 Corinthians 1-6, Brill, Leiden. 
Clarke, A.D., 2000, Serve the community of the church: Christians as leaders and ministers, Eerdmans, Grand Rapids, Ml.

Clarke, A.D., 2008, A Pauline theology of church leadership, T\&T Clark, London.

Dunn, J.D.G., 1998, The theology of Paul the apostle, Eerdmans, Grand Rapids, MI.

Ehrensperger, K., 2007, Paul and the dynamics of power: Communication and interaction in the early Christ-movement, T\&T Clark, London.

Fee, G.D., 2011, God's empowering presence, Baker Academic, Grand Rapids, MI.

French, J.R.P. \& Raven, B., 1959, 'The bases of social power', in D. Cartwright (ed.), Studies in social power, pp. 150-167, University of Michigan, Ann Arbor, MI.

Garlington, D.B., 1990, 'The obedience of faith in the Letter to the Romans part I: The

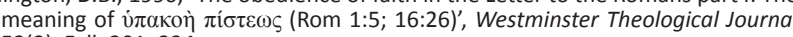
52(2), Fall, 201-224.

Garrett, S.R., 1992, 'Sociology: Sociology of early Christianity', in D.N. Friedman (ed.), The Anchor Yale Bible dictionary, vol. 6, pp. 89-99, Doubleday, New York.

Kraybill, J.N., 1999, 'Power and authority: Helping the church face problems and adapt to change', The Conrad Grebel Review 17(1), 17-34.

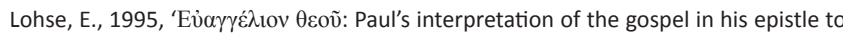
the Romans', Biblica 76(1), 127-140.

Malherbe, A.J., 1983, 'Exhortation in First Thessalonians', Novum Testamentum 25(3), 238-256. http://dx.doi.org/10.1163/156853683X00041

Malherbe, A.J., 1987, Paul and the Thessalonians: The philosophic tradition of pastoral care, Fortress Press, Philadelphia, PA.

Malherbe, A.J., 2008, The Letters to the Thessalonians: A new translation with introduction and commentary, Yale University Press, New Haven, CT.

Marshall, C.D., 2004, 'The wisdom of knowing nothing: Pauline perspectives on leadership, ministry, and power', Vision (Winnipeg, Man.) 5(2), 63-70.

Northouse, P.G., 2013, Leadership: Theory and practice, 6th edn., Sage, Los Angeles, CA.

O'Brien, P.T., 1995, Gospel and mission in the writings of Paul: An exegetical and theological analysis, Baker, Grand Rapids, MI.

Papademetriou, G.C., 2003, 'Leadership in the parish: A theology of ministry', The Greek Orthodox Theological Review 48(1-4), 113-130.

Polaski, S.H., 1999, Paul and the discourse of power, Sheffield Academic Press, Sheffield.
Raven, B.H., 1992, 'A power/interaction model of interpersonal influence: French and Raven thirty years later', Journal of Social Behavior and Personality 7(2), 217-244.

Raven, B.H., 1999, 'Kurt Lewin address: Influence, power, religion, and the mechanisms of social control', Journal of Social Issues 55(1), 161-186. http://dx.doi. org/10.1111/0022-4537.00111

Raven, B.H., 2008, 'The bases of power and the power/interaction model of interpersonal influence', Analyses of Social Issues and Public Policy 8(1), 1-22. http://dx.doi.org/10.1111/j.1530-2415.2008.00159.x

Ridderbos, H.N., 1975, Paul: An outline of his theology, transl. J.R. De Witt, Eerdmans, Grand Rapids, MI.

Shaw, G., 1983, The cost of authority: Manipulation and freedom in the New Testament, SCM Press, London.

Strawbridge, J.R., 2009, 'The word of the cross: Mission, power, and the theology of leadership', Anglican Theological Review 91(1), 61-79.

Tidball, D., 2012, 'Leaders as servants: A resolution of the tension', Evangelical Review of Theology 36(1), 31-47.

Van Rensburg, F.J., 2000, 'Dékor of konteks? - Die verdiskontering van sosio-historiese gegewens in interpretasie van ' $\mathrm{n}$ Nuwe Testament-teks vir die prediking en pastoraat, geïllustreer aan die hand van die 1 Petrus-brief' ['Décor or context? The utilisation of socio-historic data in the interpretation of a New Testament text for preaching and pastorate, illustrated with First Peter'], Skrifen Kerk 21(3), 564-582.

Van Rensburg, J.J.J., 1986, 'An argument for reading ví $\pi 10$ in 1 Thessalonians 2:7', in J.H. Petzer \& P.J. Hartin (eds.), A South African perspective on the New Testament: Essays by South African New Testament scholars presented to Bruce Manning Metzger during his visit to South Africa in 1985, pp. 252-259, Brill, Leiden.

Wanamaker, C.A., 1990, The Epistles to the Thessalonians: A commentary on the Greek text, Eerdmans, Grand Rapids, MI. (New International Greek Testament Commentary).

Weima, J.A.D., 1997, 'An apology for the apologetic function of 1 Thessalonians 2.1-12', Journal for the Study of the New Testament 68, 73-99.

Weima, J.A.D., 2002, 'Infants, nursing mother, and father: Paul's portrayal of a pastor', Calvin Theological Journal 37, 209-229.

Winter, B.W., 1993 'The entries and ethics of orators and Paul (1 Thessalonians 2:1-12)', Tyndale Bulletin 44(1), 55-74.

Yukl, G.A., 2010, Leadership in organizations, 7th edn., Pearson, Upper Saddle River, NJ. 